\title{
MAKALAH ANALISIS LAPORAN KEUANGAN
}

"Analisis Sumber Dan Penggunaan Modal Kerja"

Makalah ini disusun untuk Memenuhi Tugas Kelompok

Mata Kuliah Analisis Laporan Keuangan
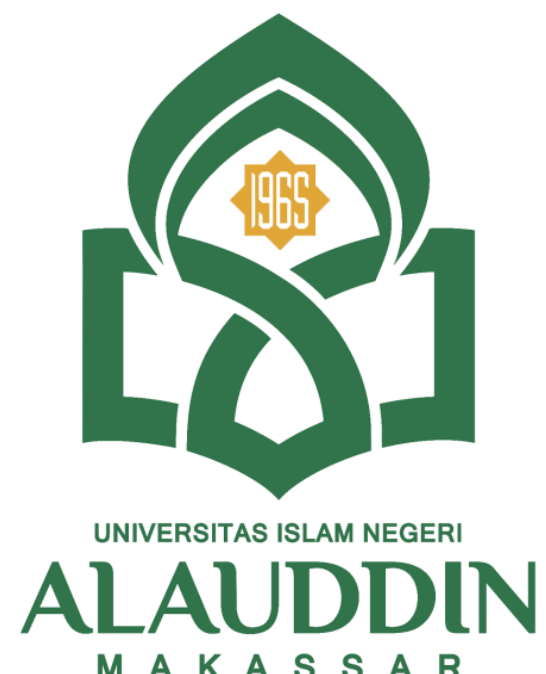

DISUSUN OLEH :

KELOMPOK 8

NUR SHINTA JAMAL (90500119031)

PUTRI AMALIA YUNUS (90500119029)

JURUSAN PERBANKAN SYARIAH

FAKULTAS EKONOMI DAN BISNIS ISLAM

UNIVERSITAS ISLAM NEGERI MAKASSAR

TAHUN 2021/2022 


\section{KATA PENGANTAR}

Puji syukur penulis panjatkan atas kehadirat Allah SWT. Yang telah memberikan rahmat dan karunia yang dilimpahkan-Nya kepada penulis, sehingga dapat menyelesaikan makalah ini yang berjudul "ANALISIS SUMBER DAN PENGGUNAAN MODAL KERJA"

Makalah ini kami buat dalam rangka memenuhi tugas mata kuliah Analisis laporan Keuangan. Dengan membuat makalah ini, dengan keterbatasan ilmu yang kami miliki, kami berusaha mencari sumber dari berbagai sumber informasi.

Kami menyadari bahwa makalah ini jauh dari kata kesempurnaan. Oleh karena itu , kritik dan saran dari semua pihak yang bersifat membangun selalu kami harapkan demi kesempurnaan makalah ini. Semoga penyusunan makalah ini dapat bermanfaat dan berguna bagi para pembaca. Akhir kata kami ucapkan terima kasih.

Gowa, 07 Desember 2021 


\section{DAFTAR ISI}

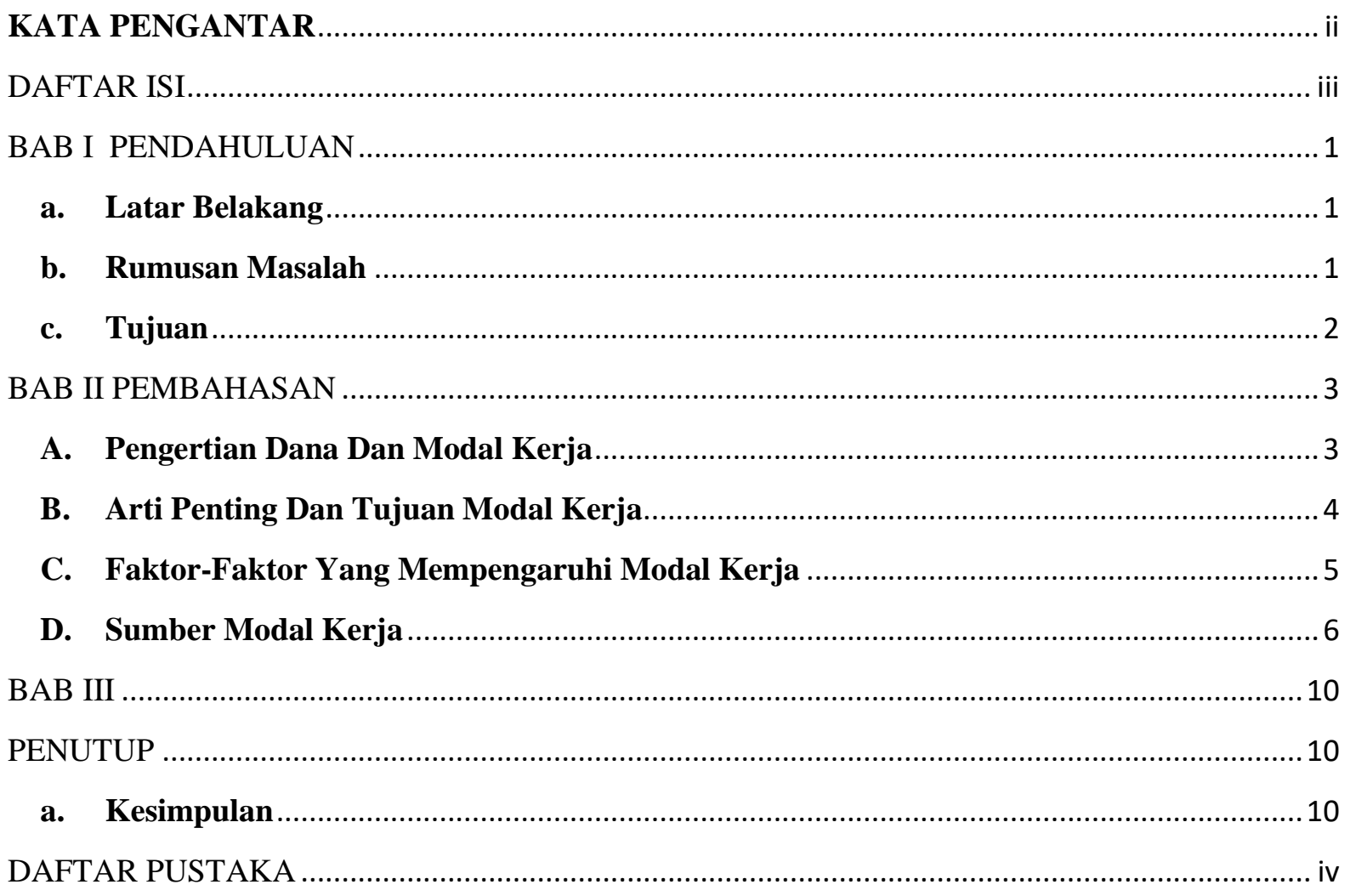




\section{BAB I \\ PENDAHULUAN}

\section{a. Latar Belakang}

Bidang keuangan merupakan bidang yang sangat penting dalam suatu perusahaan. Untuk dapat melihat kinerja suatu perusahaan dapat dilihat dari informasi keuanganya yaitu berupa Laporan Keuangan. Laporan keuangan yang biasa dibuat oleh perusahaan biasanya terdiri dari neraca, laporan laba rugi, laporan laba di tahan, laporan arus kas, dan catatan atas laporan keuangan. Namun ada pula perusahaan yang menyusun selain kelima laporan tersebut. Seperti laporan sumber dan penggunaan modal kerja yang berguna bagi para investor, kreditor, analisis sekuritas, dan manajemen karena memberikan informasi yang berguna mengenai aktivitas investasi dan pembelanjaan yang dilakukan oleh perusahaan.

Penilaian kinerja dapat dilakukan dengan cara melakukan analisis laporan keuangan. Teknis analisis yang digunakan salah satunya adalah analisis sumber dan penggunaan modal kerja yang merupakan suatu bentuk analisis modal kerja yang dimiliki perusahaan dalam periode tertentu. Sedangkan modal kerja itu sendiri merupakan keseluruhan aktiva lancar yang dimiliki oleh suatu perusahaan atau dapat pula dimaksudkan sebagai dana yang harus tersedia untuk membiayai kegiatan operasi sehari hari. Modal kerja sangat berpengaruh bagi suatu perusahaan. Adanya modal kerja yang cukup memungkinkan bagi perusahaan dalam melaksanakan aktivitasnya sehingga likuiditas perusahaan tidak mengalami kesulitan dan hambatan yang mungkin timbul.

Analisis sumber dan penggunaan modal kerja merupakan alat analisis keuangan yang sangat penting bagi perusahaan. Dengan analisis sumber dan penggunaan modal kerja, akan dapat diketahui bagaimana perusahaan mengelola atau menggunakan modal kerja yang dimilikinya sehingga perusahaan dapat menjalankan operasi dengan sebaik-baiknya. Penggunaan modal kerja yang tepat akan menyebabkan terjadinya kenaikan dalam modal kerja tersebut, dan sebaliknya penggunaan modal kerja yang tidak sesuai dengan kebutuhan perusahaan akan mengakibatkan perusahaan mengalami penurunan modal kerja yang berakibat kepada operasional perusahaan yang tidak efektif dan efisien dalam pengelolaan modal kerja. Salah satu penyebab penurunan modal kerja dalam penelitian tersebut dikarenakan adanya investasi yang terlalu besar dalam aktiva tetapnya.

\section{b. Rumusan Masalah}

1. Menjelaskan Pengertian dana dan Modal kerja ?

2. Menjelaskan arti penting dan tujuan modal kerja ?

3. Menjelasakan faktor-faktor yang mempengaruhi modal kerja ?

4. Menjelaskan sumber modal kerja ? 


\section{c. Tujuan}

1. Untuk mengetahui Pengertian dana dan Modal kerja

2. Untuk mengetahui arti penting dan tujuan modal kerja

3. Untuk mengetahui faktor-faktor yang mempengaruhi modal kerja

4. Untuk mengetahui sumber modal kerja 


\section{BAB II \\ PEMBAHASAN}

\section{A. Pengertian Dana Dan Modal Kerja}

Sering terdapat perbedaan tentang pengertian dana dalam laporan keuangan. Dana bisa diartikan sebagai "modal kerja" selain itu dana juga bisa diartikan sebagai "kas", ada juga pengertian lain dari dana sebagai "kas dan aktiva-aktiva lain yang mempunyai sifat sama dengan kas. Adapun dalam pembahasan lebih lanjut dana diartikan sebagai modal kerja. Modal kerja adalah keseluruhan aktiva lancar yang dimiliki perusahaan, atau dapat pula dimaksudkan sebagai dana yang harus tersedia untuk membiayai kegiatan operasi perusahaan sehari-hari (Rezki Rangkuti, 2004). Menurut Mamduh $(2011,519)$ Modal kerja kotor biasanya mengacu pada aktiva lancar, yang biasanya meliputi kas, piutang dagang dan persediaan. Modal kerja bersih biasanya diartikan sebagai aktiva lancar dikurangi utang lancar. Menurut Munawir $(2007$,$) penggunaan modal kerja akan menyebabkan perubahan$ bentuk maupun penurunan jumlah aktiva lancar yang dimiliki perusahaan, tetapi penggunaan aktiva lancar tidak selalu diikuti dengan berubahnya atau turunnya jumlah modal kerja yang dimiliki perusahaan. ${ }^{1}$

Dalam praktiknya dana yang dimiliki oleh perusahaan, baik dana pinjaman maupun modal sendiri, dapat digunakan untuk dua hal. Pertama, digunakan untuk keperluan investasi. Artinya dana ini digunakan untuk membeli atau membiayai aktiva tetap dan bersifat jangka panjang yang dapat digunakan secara berulangulang, seperti pembelian tanah, bangunan, mesin, kendaraan, dan aktiva tetap lainnya. Kedua, dana digunakan untuk membiayai modal kerja, yaitu modal yang digunakan untuk pembiayaan jangka pendek, seperti pembelian bahan baku, membayar gaji dan upah, dan biaya-biaya oprasional lainnya.

Analisis sumber dan penggunaan modal kerja merupakan analisis yang berhubungan dengan sumber-sumber dana dan penggunaan dana yang berkaitan dengan modal kerja perusahaan. Artinya dari mana saja perusahaan memperoleh dana guna membiayai kegiatannya. Kemudian, dana yang sudah diperoleh tersebut digunakan untuk aktivitas apa saja.

Perolehannya dana yang dibutuhkan perusahaan cukup banyak tersedia dan untuk memperolehnya relatif tidak terlalu sulit selama memenuhi persyaratan yang dipersyaratkan. Hanya saja dari berbagai sumber yang ada perlu diseleksi terlebih dulu. Artinya pemilihan setiap sumber dana yang akan digunakan disesuaikan dengan kebutuhan perusahaan. Di samping itu, juga perlu dipikirkan untung ruginya penggunaan sumber dana yang akan dipilih dibagi ke dalam

Dalam praktiknya pengertian dana atau fund beberapa pengertian berikut ini.

1. Dana dianggap sebagai kas (uang tunai). disimpan di bank dalam

2. Dana dianggap sebagai uang yang disimpan di bank dalam bentuk giro atau tabungan.

3. Dana dianggap sebagai modal kerja.

4. Dana dianggap sebagai seluruh aktiva yang dimiliki perusahaan.

\footnotetext{
${ }^{1}$ Surantinoyo Agus, 'Analisa Laporan Sumber-Sumber Dan Penggunaan Modal Kerja Dalam Meningkatkan Profitabilitas Perusahaan Pada Pt. Fast Food. Tbk', Jurnal Berkala Ilmiah Efisiensi, 16.3 (2016), 1-13.
} 
5. Dana dianggap sebagai aktiva yang memiliki sifat sama dengan kas.

Sebagai uang kas, artinya dana seperti yang tertera di dalam neraca dan langsung dapat menjadi uang tunai saat dibutuhkan. Sebagai kas dapat diartikan bahwa dana yang sesungguhnya yang dimiliki perusahaan dan siap digunakan setiap waktu dibutuhkan.

\section{B. Arti Penting Dan Tujuan Modal Kerja}

Modal kerja memiliki arti yang sangat penting bagi operasional suatu perusahaan. Di samping itu, manajemen modal kerja juga memiliki tujuan tertentu yang hendak dicapai. Oleh karena itu, setiap perusahaan berusaha memenuhi kebutuhan modal kerjanya, agar dapat meningkatkan likuiditasnya. Kemudian, dengan terpenuhi modal kerja, perusahaan juga dapat memaksimalkan perolehan labanya. Perusahaan dalam kekurangan modal kerja dapat membahayakan kelangsungan hidup perusahaan yang bersangkutan, akibat tidak dapat memenuhi likuiditas dan target laba yang diinginkan. Kecukupan modal kerja juga merupakan salah satu ukuran kinerja manajemen.

Secara umum arti penting modal kerja bagi perusahaan, terutama bagi kesehatan keuangan perusahaan, yaitu sebagai berikut.

1. Kegiatan seorang manajer keuangan lebih banyak dihabiskan di dalam kegiatan operasional perusahaan dari waktu ke waktu. Ini merupakan manajemen modal kerja.

2. Investasi dalam aktiva lancar cepat dan sering kali mengalami perubahan serta cenderung labil. Sedangkan aktiva lancar adalah modal kerja perusahaan, artinya perubahan tersebut akan berpengaruh terhadap modal kerja. Oleh karena itu, perlu mendapat perhatian yang sungguh-sungguh dari manajer keuangan.

3. Dalam praktiknya sering kali bahwa separuh dari total aktiva merupakan bagian dari aktiva lancar, yang merupakan modal kerja perusahaan. Dengan kata lain, jumlah aktiva lancar sama atau lebih dari 50\% datri total aktiva.

4. Bagi perusahaan yang relatif kecil, fungsi modal kerja amat penting. Perusahaan kecil, relatif terbatas untuk memasuki pasar dengan modal besar dan jangka panjang. Pendanaan perusahaan lebih mengandalkan pada utang jangka pendek, seperti utang dagang, utang bank satu tahun yang tentunya dapat memengaruhi modal kerja.

5. Terdapat hubungan yang sangat erat antara pertumbuhan penjualan dengan kebutuhan modal kerja. Kenaikan penjualan berkaitan dengan tambahan, piutang, sediaan dan juga saldo kas. Demikian pula sebaliknya apabila terjadi penurunan penjualan, akan berpengaruh terhadap komponen dalam aktiva lancar.

Kemudian, tujuan manajemen modal kerja bagi perusahaan adalah:

1. guna memenuhi kebutuhan likuiditas perusahaan.

2. dengan modal kerja yang cukup perusahaan memiliki kemampuan untuk memenuhi kewajiban pada waktunya;.

3. memungkinkan perusahaan untuk memiliki cukup dalam rangka memenuhi kebutuhan tambahan pelanggannya;

4. memungkinkan perusahaan untuk memperoleh dana dari para kreditor, apabila rasio keuangannya memenuhi kredit syarat; 
5. memungkinkan perusahaan memberikan syarat yang menarik minat pelanggan, dengan kemampuan yang dimilikinya. ${ }^{2}$

\section{Faktor-Faktor Yang Mempengaruhi Modal Kerja}

Faktor-faktor yang mempengaruhi modal kerja menurut Djarwanto (2011:91-94) adalah sebagai berikut :

1. Sifat umum atau tipe perusahaan Modal kerja yang dibutuhkan perusahaan jasa (public utility) relatif randah karena investasi dalam persediaan dan piutang pencairannya menjadi kas relatif cepat. Untuk beberapa perusahaan jasa tertentu malahan langganan membayar di muka sebelum jasa dinikmati. Sedangkan perusahaan industri memerlukan modal kerja yang cukup besar, yakni untuk melakukan investasi dalam bahan baku, barang dalam proses, dan barang jadi.

2. Waktu yang diperlukan untuk memproduksi atau mendapatkan barang dan ongkos produksi per unit/harga beli per unit barang itu Jumlah modal kerja berkaitan langsung dengan waktu yang dibutuhkan mulai dari bahan baku atau barang jadi dibeli sampai barang dijual kepada langganan. Makin panjang waktu yang diperlukan untuk memproduksi barang atau untuk memperoleh barang makin besar kebutuhan akan modal kerja.

3. Syarat pembelian dan penjualan Syarat kecil pembelian barang dagangan atau bahan baku akan mempengaruhi besar-kecilnya modal kerja. Syarat kredit pembelian yang menguntungkan akan memperkecil kebutuhan uang kas yang harus ditanamkan dalam persediaan, sebaliknya bila pembayaran harus dilakukan segera setelah barang diterima maka kebutuhan uang kas untuk membelanjai volume perdagangan menjadi lebih besar.

4. Tingkat perputaran persediaan Semakin sering persediaan diganti (dibeli dan dijual kembali) maka kebutuhan modal kerja yang ditanamkan dalam bentuk persediaan (barang) akan semakin rendah.

5. Tingkat perputaran piutang Kebutuhan modal kerja juga tergantung pada periode waktu yang diperlukan untuk mengubah piutang menjadi uang kas. Bila piutang terkumpul dalam waktu pendek berarti kebutuhan akan modal kerja menjadi semakin rendah/kecil. Untuk mencapai tingkat perputaran piutang yang tinggi diperlukan pengawasan piutang yang efektif dan kebijaksanaan yang tepat sehubungan dengan perluasan kredit, syarat kredit penjualan, maksimum kredit bagi langganan, penagihan piutang.

6. Pengaruh konjungtur (business cycle) Pada periode makmur aktivitas perusahaan meningkat dan perusahaan cenderung membeli barang-barang lebih banyak dengan memanfaaatkan harga yang masih rendah.

7. Derajat risiko kemungkinan menurunnya harga jual aktiva jangka pendek Menurunnya nilai riil dibandingkan dengan harga buku dari surat-surat berharga, persediaan barang dan piutang akan menurunkan modal kerja. Bila risiko kerugian ini semakin besar berarti diperlukan tambahan modal kerja untuk membayar bunga atau melunasi utang jangka pendek yang sudah jatuh tempo.

8. Pengaruh musim Banyak perusahaan dimana penjualannya hanya terpusat pada beberapa bulan saja. Perusahaan yang dipengaruhi oleh musim membutuhkan jumlah maksimum modal kerja untuk periode yang relatif pendek. Modal kerja yang ditanamkan dalam bentuk persediaan barang berangsur-angsur meningkat dalam bulan-bulan menjelang puncak penjualan.

\footnotetext{
${ }^{2}$ Dr. Kasmir, S.E., M.M. Analisis Laporan Keuangan. Depok :PT RajaGrafindo Persada, 2008.
} 
9. Credit rating dari perusahaan Jumlah modal kerja, dalam bentuk kas termasuk surat-surat berharga yang dibutuhkan perusahaan untuk membiayai operasinya tergantung pada kebijaksanaan penyediaan uang kas.

Faktor-faktor yang mempengaruhi modal kerja menurut Kasmir (2016:254) yaitu :

1. Jenis Perusahaan Jenis kegiatan perusahaan dalam praktiknya meliputi dua macam yaitu perusahaan yang bergerak dalam bidang jasa dan non jasa (industri). Kebutuhan modal dalam perusahaan industri lebih besar jika dibandingkan dengan perusahaan jasa. Diperusahaan industri, investasi dalam bidang kas, piutang dan persediaan relatif lebih besar jika dibandingkan dengan perusahaan sangat menentukan kebutuhan akan modal kerjanya.

2. Syarat Kredit Syarat Kredit atau penjualan yang pembayarannya dilakukan dengan mencicil (angsuran) juga sangat mempengaruhi modal kerja. Untuk meningatkan penjualan bisa dilakukan dengan berbagai cara dan salah satunya adalah melalui penjualan secara kredit. Penjualan barang secara kredit memberikan kelonggaran kepada konsumen untuk membeli barang dengan cara pembayaran diangsur (dicicil) beberapa kali untuk jangka waktu tertentu. Hal yang perlu diketahui dari syarat-syarat kredit dalam hal ini adalah :

a. Syarat untuk pembelian bahan atau barang dagangan Syarat untuk pembelian bahan atau barang yang akan digunakan untuk memproduksi barang mempengaruhi modal kerja. Pengaruhnya berdampak terhadap pengeluaran kas. Jika persyaratan kredit lebih mudah, akan sedikit uang kas yang keluar demikian pula sebaliknya, syarat untuk pembelian bahan atau barang dagangan juga memiliki kaitannya dengan sediaan.

b. Syarat Penjualan Barang Dalam syarat penjualan, apabila syarat kredit diberikan relatif lunak seperti potongan harga, modal kerja yang dibutuhkan semakin besar dalam sektor piutang. Syarat-syarat kerdit yang diberikan apakah 2/10 net 30 atau $2 / 10$ net 60 juga akan mempengaruhi penjualan kredit. Agar modal kerja diinvestasikan dalam sektor piutang dapat diperkecil, perusahaan perlu memberikan potongan harga. Kebijakan ini disamping bertujuan untuk menarik minat debitur untuk segera membayar utangnya, juga untuk memperkecil kemungkinan risiko utang yang tidak tertagih (macet).

c. Waktu Produksi Untuk waktu produksi, artinya jangka waktu yang digunakan untuk memproduksi suatu barang, maka akan semakin besar modal kerja yang dibutuhkan. Demikian pula sebaliknya semakin pendek waktu yang dibutuhkan untuk memproduksi modal kerja, maka semakin kecil modal kerja yang dibutuhkan.

d. Tingkat Perputaran Sediaan Pengaruh tingkat perputaran sediaan terhadap modal kerja cukup penting bagi perusahaan. Semakin kecil atau rendah tingkat perputaran, kebutuhan modal kerja semakin tinggi, demikian pula sebaliknya. Dengan demikian dibutuhkan perputaran sediaan yang cukup tinggi agar memperkecil risiko kerugian akibat penurunan harga serta mampu menghemat biaya penyimpanan dan pemeliharaan sediaan.

\section{Sumber Modal Kerja}

Sumber-sumber modal kerja bagi perusahaan menurut Munawir (2014:12) adalah sebagai berikut :

1. Hasil Operasi Perusahaan Jumlah net income yang tampak dalam laporan perhitungan laba rugi ditambah dengan depresiasi dan amortisasi, jumlah ini menunjukkan jumlah modal kerja 
yang berasal dari operasi perusahaan dapat dihitung dengan menganalisa laporan keuangan laba rugi perusahaan tersebut dan apabila laba tersebut tidak diambil oleh perusahaan maka laba tersebut akan menambah modal perusahaan yang bersangkutan.

2. Keuntungan dari Penjualan Surat-Surat Berharga Surat berharga yang dimiliki perusahaan untuk jangka pendek adalah satu elemen aktiva lancar yang segera dapat dijual akan dapat menimbulkan keuntungan bagi perusahaan.

3. Penjualan Aktiva Tidak Lancar Sumber lain yang dapat menambah modal kerja adalah hasil penjualan aktiva tetap, investasi jangka panjang dan aktiva tidak lancar lainnya yang tidak diperlukan lagi oleh perusahaan. Perubahan dari aktiva ini menjadi kas atau piutang akan menyebabkan bertambahnya modal kerja sebesar hasil penjualan tersebut.

4. Penjualan Saham atau Obligasi Untuk menambah dana atau modal kerja yang dibutuhkan, perusahaan dapat pula mengadakan emisi saham baru atau meminta kepada para pemilik perusahaan untuk menambah modalnya, disamping itu perusahaan dapat juga mengeluarkan obligasi atau bentuk hutang jangka panjang lainnya guna memenuhi modal kerja.

Pada umumnya sumber modal kerja suatu perusahaan menurut Kasmir (2016:256) berasal dari :

1. Hasil operasi perusahaan Adalah pendapatan atau laba yang diperoleh pada periode tertentu.

2. Keuntungan penjualan surat-surat berharga Adalah selisih antara harga beli dengan harga jual surat berharga tersebut.

3. Penjualan saham adalah perusahaan melepas sejumlah saham yang dimiliki untuk dijual kepada berbagai pihak.

4. Penjualan aktiva tetap Adalah yang dijual yaitu aktiva tetap yang kurang produktif atau masih menganggur.

5. Penjualan obligasi Adalah perusahaan mengeluarkan sejumlah obligasi untuk dijual kepada pihak lainnya.

6. Memperoleh pinjaman Adalah pinjaman dari pihak kreditor (bank atau lembaga lain).

7. Dana hibah dan

8. Sumber lainnya.

Pengaruh Profitabilitas Terhadap Nilai PerusahaanBerdasarkan hasil pengujian hipotesis ketiga secara parsial, dapat diketahui bahwa variabel profitabilitas memiliki nilai koefisien regresi dengan nilai signifikansi sebesar 0.002 yang lebih kecil dari 0.05 . Sehingga perhitungan variabel profitabilitas memperoleh hasil bahwa profitabilitas berpengaruh signifikan dan positif terhadap nilai perusahaan yang terdaftar di jakarta islamic index. Yang berarti bahwa ketika profitabilitas semakin meningkat maka nilai perusahaan suatu perusahaan akan meningkat.

Meningkatnya pendapatan bersih suatu perusahaan dapat pula meningkatkan profitabilitas yang diwakilkan dengan indikator ROE (return on equity) dan indikator ROA (return on asset) oleh karena peningkatan profitabilitas ini maka harga saham perusahaan meningkat sehingga menambah nilai perusahaan. Adanya pengaruh positif dan signifikan profitabilitas terhadap nilai perusahaan dapat dimungkinkan karena sentiment positif para pelaku pasar (investor) untuk membeli saham yang dikarenakan investor melihat terjadi kenaikan laba bersih perusahaan sepanjang tahun pengamatan, sehingga investor memandang bahwa kinerja perusahaan Jakarta Islamic Index sangat baik. Pendapat tersebut sebagai hasil penelitian yang diperoleh telah didukung dan sesuai dengan salah satu teori signaling yang menyatakan bahwa ketika investor menerima informasi yang baik terhadap kinerja suatu perusahaan, maka investor akan bereaksi yaitu membeli saham. Semakin banyak investor yang 
tertarik, maka harga saham yang tercipta akan meningkat dan meningkatnya harga saham membuat nilai perusahaan akan meningkat pula. 29 Hasil penelitian ini juga sejalan dengan teori Husnan yang menyatakan bahwa semakin baik pertumbuhan profitabilitas perusahaan berarti prospek perusahaan dimasa depan dinilai semakin baik, artinya nilai perusahaan juga akan dinilai semakin baik di mata investor.

Apabila kemampuan perusahaan untuk menghasilkan laba meningkat, maka harga saham juga akan meningkat. Dengan demikian semakin tinggi rasio ini maka akan semakin baik posisi perusahaan yang berarti semakin besar kemampuan perusahaan untuk menutupi investasi yang digunakan. Hal ini dapat memungkinkan perusahaan untuk membiayai investasi dari dana yang berasal dari sumber internal yang tersedia dalam laba ditahan, sehingga informasi dalam ROA akan menjadi nilai positif bagi investor dan dapat meningkatkan nilai perusahaan.

Pengaruh Growth Opportunity Terhadap Nilai PerusahaanBerdasarkan hasil perhitungan uji hipotesis secara parsial (uji t), diperoleh nilai signifikansi variabel growth opportunity sebesar 0.000 yang artinya nilai tersebut ternyata lebih kecil dari tingkat signifikansi yang ditetapkan sebesar 0.05 . Hal ini berarti terdapat pengaruh signifikan antara variabel growth opportunity dengan variabel nilai perusahaan sehingga hipotesis dalam penelitian ini diterima karena didukung oleh data penelitian dan menunjukkan bahwa growth opportunity mempunyai pengaruh positif dan signifikan terhadap nilai perusahaan. Dari hasil penelitian ini juga, diperoleh hasil koefisien regresi variabel growth opportunity sebesar 6.083. koefisien regresi growth opportunity bertanda positif sehingga menunjukkan variabel growth opportunity ini memiliki arah pengaruh secara positif dan signifikan terhadap struktur modal perusahaan yang terdaftar di Jakarta Islamic Index periode 2011-2015. Dengan arah pengaruh tersebut menandakan bahwa semakin tinggi growth opportunity, maka nilai perusahaan semakin meningkat.

Berdasarkan pada leverage, perusahaan dengan tingkat pertumbuhan yang tinggi sebaiknya menggunkan ekuitas sebagai sumber pembiayaan untuk menghindari biaya keagenan antara pemegang saham dan manajemen perusahaan. Sebaliknya, menggunakan utang sebagai sumber pembiayaan karena penggunaan utang mengharuskan perusahaan tersebut membayar bunga secara teratur. Selain itu, dalam memenuhi kebutuhan untuk membiayai pertumbuhannya banyak perusahaan menggunakan utang sehingga memungkinkan modal asing dari pihak eksternal paling diutamakan terlebih dahulu sebagai sumber alternatif pertama untuk mendanai kegiatan perusahaan dalam mencapai pertumbuhan yang tinggi. Hal ini terjadi karena perusahaan yang berpeluang untuk mencapai pertumbuhan yang tinggi pasti akan mendorong perusahaan untuk terus melakukan ekspansi Walaupun penggunaan utang memberikan manfaat tetapi karena penambahan/peningkatan jumlah modal asing atau utang jangka panjang yang terlalu berlebihan darip da modal sendiri justru akan memperbesar resiko perusahaan, yaitu meningkatnya peluang kebangkrutan sehingga dapat menurunkan nilai perusahaan. 30 Pengaruh Struktur Modal Terhadap Nilai Perusahaan.

Berdasarkan hasil pengujian hipotesis kelima secara parsial, dapat diketahui bahwa variabel struktur modal memiliki nilai koefisien regresi dengan nilai signifikansi sebesar 0.002 yang lebih kecil dari 0.05. Sehingga perhitungan variabel struktur modal memperoleh hasil bahwa profitabilitas berpengaruh signifikan dan positif terhadap nilai perusahaan yang terdaftar di jakarta Islamic index. Berdasarkan pengujian hipotesis, dapat dijelaskan struktur modal berpengaruh positif terhadap nilai perusahaan perusahaan dengan signifikan. Pengujian hipotesis ini dapat diartikan bahwa penambahan utang yang dilakukan oleh perusahaan untuk melakukan ekspansi usaha akan meningkatkan harga saham dari perusahaan tersebut, sehingga nilai perusahaan meningkat signifikan. Penelitian menegaskan bahwa struktur modal dari perusahaan properti dan real estate di BEI belum mencapai 
titik optimalnya, sesuai dengan teori MM yang menyatakan apabila terjadi peningkatan nilai perusahaan akan disebabkan oleh penambahan utang selama struktur modal berada di bawah titik optimalnya, hal tersebut dijelaskan oleh Trade-off Theory dimana manfaat dari peningkatan utang masih lebih besar dari pengorbanan yang dikeluarkan sehingga secara langsung manfaat penggunaan utang tersebut meningkatkan nilai perusahaan. Peningkatan nilai perusahaan karena peningkatan jumlah utang (utang masih di bawah titik optimalnya) disebabkan oleh manajemen perusahaan yang menggunakan utang tersebut untuk ekspansi usaha dari perusahaan. Pengaruh Profitabilitas Terhadap Nilai Perusahaan Melalui Struktur Modal

Berdasarkan hasil pengujian analisis jalur (path analysis) diperoleh hasil bahwa struktur modal tidak dapat memediasi pengaruh profitabilitas terhadap nilai perusahaan, hal ini dapat dilihat dari pengujian pengaruh struktur modal sebagai variabel intervening dengan melihat nilai t hitung sebesar -0.7325761646 yang lebih kecil dari t tabel dengan tingkat signifikansi 0.05 yaitu sebesar 1.668, yang berarti bahwa koefisien mediasi sebesar -0.00431 tidak memiliki pengaruh mediasi. Berdasarkan pada penelitian ini struktur modal tidak dapat memediasi hubungan antara profitabilitas dan nilai perusahaan namun profitabilitas dapat mempengaruhi nilai perusahaan secara langsung. Hal ini disebabkan perusahaan dengan tingkat profitabilitas (profitability) yang tinggi mampu membiayai kegiatan usahanya dengan laba ditahan yang dimilikinya, sehingga perusahaan tersebut akan menggunakan utang dalam jumlah yang relatif sedikit. Hasil ini didukung oleh Elim dan Yusfarita yang menyatakan profitabilitas (ROA) mempunyai pengaruh negatif namun signifikan terhadap struktur modal, begitu pula dengan Kazemi dan Ansari didalam penelitiannya menyatakan bahwa profitabilitas (profitability) negatif signifikan terhadap semua rasio utang. Temuan penelitian ini mendukung hasil penelitian Mas'ud yang menyatakan bahwa terdapat hubungan positif antara profitabilitas (profitability) dengan struktur modal perusahaan.

Kesimpulan penelitiannya menunjukkan bahwa perusahaan manufaktur yang terdaftar di Bursa Efek Indonesia (BEI) dalam menjalankan aktivitasnya belum efisien, terlihat dari masih relatif kecilnya keuntungan yang diperoleh terhadap investasi aktiva.31 Berdasarkan hubungannya dengan profitabilitas dan nilai perusahaan bahwa Perusahaan yang memiliki profitabilitas besar setiap tahunnya, cenderung diminati oleh banyak investor. Para investor beranggapan bahwa perusahaan yang mempunyai profit besar akan menghasilkan return yang besar pula. Hal ini ditangkap oleh investor sebagai sinyal positif dari perusahaan, sehingga akan meningkatkan kepercayaan investor serta akan mempermudah manajemen perusahaan untuk menarik modal dalam bentuk saham. Apabila terdapat kenaikkan permintaan saham suatu perusahaan, maka secara tidak langsung akan menaikkan harga saham perusahaan tersebut di pasar modal. Pengaruh Growth Opportunity Terhadap Nilai Perusahaan Melalui Struktur Modal Berdasarkan hasil pengujian analisis jalur (path analysis) diperoleh hasil bahwa struktur modal dapat memediasi pengaruh growth opportunity terhadap nilai perusahaan, hal ini dapat dilihat dari pengujian pengaruh struktur modal sebagai variabel intervening variabel struktur modal memiliki t hitung $=2.0828654381$ lebih besar dari $\mathrm{t}$ tabel dengan tingkat signifikansi 0.05 yaitu sebesar 1.668 maka dapat disimpulkan bahwa koefisien mediasi signifikan yang berarti ada pengaruh mediasi. Berdasarkan pada penelitian ini struktur modal dapat memediasi hubungan antara growth opportunity terhadap nilai perusahaan.

Disamping itu, growth opportunity juga dapat mempengaruhi nilai perusahaan secara langsung. Hal ini disebabkan perusahaan yang berpeluang untuk mencapai pertumbuhan yang tinggi pasti akan mendorong perusahaan untuk terusmelakukan ekspansi Walaupun penggunaan utang memberikan manfaat tetapi karena penambahan/peningkatan jumlah modal asing atau utang jangka panjang yang terlalu berlebihan daripada modal sendiri justru akan memperbesar resiko perusahaan, yaitu meningkatnya peluang kebangkrutan sehingga dapat menurunkan nilai perusahaan. 


\section{BAB III}

\section{PENUTUP}

\section{a. Kesimpulan}

Dana bisa diartikan sebagai "modal kerja" selain itu dana juga bisa diartikan sebagai "kas", ada juga pengertian lain dari dana sebagai "kas dan aktiva-aktiva lain yang mempunyai sifat sama dengan kas. Adapun dalam pembahasan lebih lanjut dana diartikan sebagai modal kerja. Modal kerja adalah keseluruhan aktiva lancar yang dimiliki perusahaan, atau dapat pula dimaksudkan sebagai dana yang harus tersedia untuk membiayai kegiatan operasi perusahaan sehari-hari.

Modal kerja memiliki arti yang sangat penting bagi operasional suatu perusahaan. Di samping itu, manajemen modal kerja juga memiliki tujuan tertentu yang hendak dicapai. Oleh karena itu, setiap perusahaan berusaha memenuhi kebutuhan modal kerjanya, agar dapat meningkatkan likuiditasnya. Kemudian, dengan terpenuhi modal kerja, perusahaan juga dapat memaksimalkan perolehan labanya. Perusahaan dalam kekurangan modal kerja dapat membahayakan kelangsungan hidup perusahaan yang bersangkutan, akibat tidak dapat memenuhi likuiditas dan target laba yang diinginkan. Kecukupan modal kerja juga merupakan salah satu ukuran kinerja manajemen 


\section{DAFTAR PUSTAKA}

Djarwanto. 2011. Pokok-Pokok Analisis Laporan Keuangan. Yogyakarta: BPFE

http://www.ejournal.alqolam.ac.id/index.php/iqtishodia/article/view/263/249

Dr. Kasmir, 2019. Analisis Laporan Keuangan. Jakarta: PT Raja Grafindo Persada.

Dr. Kasmir, S.E., M.M. Analisis Laporan Keuangan. Depok :PT RajaGrafindo Persada, 2008.

Hery. 2015. Analisis Laporan Keuangan. Edisi 1. Yogyakarta: Center For Academic

Publishing Services.

Surantinoyo Agus, 'Analisa Laporan Sumber-Sumber Dan Penggunaan Modal Kerja Dalam Meningkatkan Profitabilitas Perusahaan Pada Pt. Fast Food. Tbk', Jurnal Berkala Ilmiah Efisiensi, 16.3 (2016), 1-13.

Munawir, S. 2014. Analisis Laporan Keuangan Edisi Keempat. Cetakan Kelima Belas. Yogyakarta: Liberty.

Prastowo D, Dwi. 2015. Analisis Laporan Keuangan. Yogyakarta: UPP STIM YKPN. 